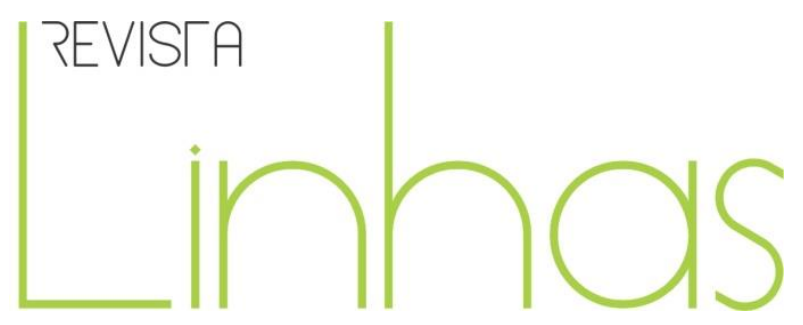

\title{
Assistência estudantil e harmonização social: em análise o Programa de Atendimento ao Estudante em Vulnerabilidade Social do Instituto Federal de Santa
} Catarina

\begin{abstract}
Resumo
O presente trabalho tem como objetivo analisar a política de Assistência Estudantil no Instituto Federal de Santa Catarina (IFSC), especificamente com a materialização do Programa de Atendimento ao Estudante em Vulnerabilidade Social (PAEVS). Investigamos o eixo norteador do programa difundido nos documentos oficiais da Instituição, cotejando seus pressupostos com o contexto societário atual. Mostramos ainda a trajetória de constituição do programa. A pesquisa é fundamentada no método histórico-dialético, com análise documental alicerçada em Kosik (2002), Garcia (2004), Shiroma, Campos e Garcia (2005) e Evangelista (2012, 2014). O estudo mostra que o programa PAEVS atua em nível estratégico para solucionar problemas de "permanência" e "êxito" estudantil, sendo norteado pela concepção de "inclusão social". Por ter atuação no tratamento compensatório dos efeitos da pobreza, acaba funcionando como instrumento que dissocia as desigualdades sociais de seus determinantes estruturais. Nesse horizonte, a "vulnerabilidade social", enaltecida pelo programa, ganha status de política focal, atuando na harmonização/coesão social e maquiando as contradições sociais em seu contexto de atuação.
\end{abstract}

Palavras-chave: Assistência Estudantil; Permanência e Êxito; Vulnerabilidade Social.

\author{
Fabrício Spricigo \\ Instituto Federal de Santa \\ Catarina - IFSC - SC/Brasil \\ fabriciospri@hotmail.com \\ Mariléia Maria da Silva \\ Universidade do Estado de Santa \\ Catarina - UDESC - SC/Brasil \\ marileiamaria@hotmail.com
}

\section{Para citar este artigo:}

SPRICIGO, Fabrício; SILVA, Mariléia Maria da. Assistência estudantil e harmonização social: em análise o Programa de Atendimento ao Estudante em Vulnerabilidade Social do Instituto Federal de Santa Catarina Revista Linhas. Florianópolis, v. 17, n. 35, p. 372-405, set./dez. 2016. 


\title{
Student assistance and social matching: analysis of the Program of Attendance to Students in Social Vulnerability at the Federal Institute of Santa
} Catarina

\begin{abstract}
The present research aims at analysing the policy of student assistance at the Federal Institute of Santa Catarina (IFSC), specifically with the implementation of the program of attendance to students in social vulnerability (PAEVS). It also investigates the guiding principles of the broadcast program in official documents of the institution, comparing their assumptions with the current social context. In addition, the constitution of the program is presented. The paper is based on historic dialectical method, grounded on Kosik (2002), Garcia (2004), Shiroma, Campos and Garcia (2005) and on Evangelista (2012, 2014). The study shows that the PAEVS program operates at a strategic level to solve problems of ongoing schooling and achievement. Due to having operations in the compensatory treatment of the effects of poverty, it ends up working as a tool that dissociates social inequalities from its structural determinants. In such scenario, social vulnerability, pointed out by the program, gains the status of main policy, acting in the social cohesion, camouflaging social contradictions in the operating context.
\end{abstract}

Keywords: Student Assistance; Ongoing Schooling and Achievement; Social Vulnerability. 


\section{Introdução}

Os problemas sociais em evidência, dentre os quais os que permeiam a educação, fazem parte do cenário da crise estrutural do capital. Mészáros (2015) mostra que as crises vivenciadas na atualidade nada têm de novas. Elas são crônicas e permanentes. Suas manifestações são o desemprego estrutural, a destruição ambiental e as guerras permanentes. O autor afirma que vivemos uma crise estrutural cada vez mais profunda, cuja superação está além das medidas paliativas para cobrir o endividamento global. Crise que se reflete na totalidade do tecido social. Acerca dos programas sociais que na atualidade buscam tornar a pobreza tolerável, Netto (2013) argumenta que não há o questionamento da ordem social vigente, apenas atuação com aspectos superficiais da questão social, não abalando o modus operandi da elite dominante. Ocorrem mudanças paliativas, que conservam o mesmo mecanismo que produz as desigualdades sociais.

Na mesma perspectiva, afirma que é esse caráter minimalista que constitui os vários programas que, por meio de transferências focalizadas de renda, têm sido difundidos nos países periféricos. Na medida em que não buscam efetivamente transformações estruturais, tais programas se 'cronificam' como emergenciais e assistencialistas. Reportando-se a Marx (1998), esclarece: “[...] a questão social para Marx é constitutiva do capitalismo: não se suprime aquela se este se conservar. [...] A análise marxiana fundada no caráter explorador do regime do capital permite situar com radicalidade histórica a questão social” (NETTO, 2013, p. 07-08).

O presente artigo tem como propósito analisar a política de Assistência Estudantil no Instituto Federal de Santa Catarina (IFSC), por meio da investigação do eixo norteador do Programa de Atendimento ao Estudante em Vulnerabilidade Social (PAEVS), caracterizando sua materialidade histórica. Conforme Resolução CONSUP/IFSC Nº 47/2014b, o programa se caracteriza pela oferta de auxílios financeiros que pretendem atender às "necessidades" de pagamento de despesas como, por exemplo, alimentação, material escolar e transporte de casa até a instituição do estudante em "vulnerabilidade social". Além disso, integra a política do IFSC para "permanência" e "êxito" acadêmico, em que um auxílio financeiro em pecúnia é concedido ao estudante vulnerável por até 10 (dez) meses no ano. 
Intriga-nos a temática da focalização do referido programa, bem como sua utilização como instrumento central das ações de assistência no IFSC, carecendo de reflexão sistematizada e questionamento conceitual a fim de cotejar os posicionamentos hegemônicos atinentes ao programa.

Nesse sentido, levantam-se os seguintes problemas e indagações para investigação: Quais os pressupostos teórico-metodológicos que fundamentam a política de Assistência Estudantil do IFSC, materializada no Programa de Atendimento ao Estudante em Vulnerabilidade Social (PAEVS)? Há contradições em sua institucionalização?

Partindo do pressuposto de que as políticas públicas educacionais não estão exclusivamente comprometidas com a igualdade substantiva (MÉSZÁROS, 2015), tem-se como hipótese que a política de assistência estudantil difundida na contemporaneidade pode atuar como armadilha ideológica, uma vez que pode obscurecer a realidade por se expressar semanticamente como sendo positiva.

O estudo em questão envolve a análise de documentos orientadores da política de Assistência Estudantil do IFSC, tanto as normativas internas quanto as legislações aplicadas à temática. Nesse sentido, é feito um mapeamento de seus documentos norteadores, editais, e atas do Conselho Superior do IFSC. Importante ressaltar que as análises se dão no movimento concreto entre o que "aparece" no documento e as referências apresentadas, tratando-os metodologicamente segundo sua abrangência (nacional/institucional) e temporalidade. Com fundamento em Evangelista (2012), Kosik (2002) e Behring (2011), compreendemos que o real não é dado a priori, mas requer esforço teórico, disciplina e ação refletida sobre o fenômeno para que sua essência possa ser desvelada. Com esse horizonte, nos apropriamos do método histórico-dialético, tomando o fenômeno de estudo em seu complexo e contraditório processo de produção e reprodução, na perspectiva de aproximação da totalidade concreta, para além da aparência imediata.

A análise dos documentos selecionados parte do pressuposto que "os termos empregados nos documentos de política educacional não são prontamente assimiláveis ou aplicáveis" (SHIROMA, CAMPOS e GARCIA, 2005, p. 430). Sua implementação requer certa tradução e interpretação de acordo com as vivências e os jogos políticos que 
perpassam a área da educação. Tomando a política como processo, uma contribuição para a análise de documentos parece vir da exploração das contradições internas às formulações, uma vez que os textos evidenciam vozes discordantes, em disputa. É nesse contexto de disputas que a hegemonia discursiva (FAIRCLOUGH, 2001) se constrói. Assim, não se aborda o texto como ponto de partida absoluto, mas como objeto para interpretação.

O artigo está organizado em quatro seções, além da introdução. Na primeira seção, trazemos aspectos importantes para compreender a base na qual Assistência Estudantil do IFSC e o Programa PAEVS estão inseridos, refletindo sobre o processo de expansão da Rede Federal de Educação Profissional e Tecnológica, com breve resgate de sua expressão na atualidade. Na segunda e terceira seções, entramos na análise do programa PAEVS como expressão fenomênica da assistência estudantil no IFSC. Nesse sentido, é realizado um percurso por seus documentos reguladores, editais, atas do Conselho Superior da instituição, desvelando os fundamentos norteadores do objeto de estudo. Por fim, na quarta seção, chegamos às considerações finais, com a síntese das reflexões propostas ao longo da pesquisa, retomando seus objetivos e questões norteadoras, compondo um quadro a respeito das discussões colocadas inicialmente e apresentando perspectivas futuras em relação à temática investigada.

\section{Lócus de pesquisa: os Institutos Federais e o IFSC}

A criação dos Institutos Federais seguiu os princípios elencados no Decreto $\mathrm{n}^{\circ}$ 6.095, de 24 de abril de 2007, intensificando-se, a partir de então, um grande processo de expansão da Rede Federal de Educação Profissional e Tecnológica. Tal decreto teve o intuito de estimular a reorganização das instituições federais de educação profissional e tecnológica (CONCEFET, 2008). No entanto, sua origem remonta ao Decreto $n^{\circ} 7.566$ de 1909, assinado pelo presidente Nilo Peçanha. Pretendia-se, naquele período, criar "uma rede de Escolas de Aprendizes e Artífices, a partir da necessidade de prover os

'desfavorecidos da fortuna', isto é, prover as classes proletárias de meios que garantissem a sua sobrevivência" (CONCEFET, 2008, p. 148). Pode-se afirmar que as instituições que compõem a rede federal de Educação Profissional, Científica e 
Tecnológica (EPCT) passaram por inúmeras transformações ao longo de seus 106 anos de existência.

Ciavatta (2010) considera que os atuais Institutos Federais têm dupla função: promover o ensino, a pesquisa e a extensão como universidades e, ainda, manter o ensino técnico de nível médio como é sua tradição. Entretanto, as políticas educacionais no Brasil não têm atendido satisfatoriamente toda população. Além disso, a gratuidade e obrigatoriedade dos cursos técnicos de nível médio não estão presentes em lei, ficando os institutos à mercê do sucesso dos programas de governo.

Segundo registro do Diretor de Desenvolvimento do Ensino do IFSC, em reunião ordinária do Conselho Superior da instituição realizada em fevereiro de 2013,

A partir de 2014 a matriz orçamentária estará vinculada à oferta de programas, Pronatec, Mulheres Mil, PROEJA e ao atendimento das diretrizes [de permanência estudantil]. Na reunião do CONIF, os gestores deixaram claro que os institutos federais só terão a liberação do orçamento pleno se cumprirem as metas propostas. (ATA CONSUP/IFSC, $1^{\text {a }}$ REUNIÃO ORDINÁRIA, 2013)

Constata-se que os Institutos Federais ficam entrelaçados ao sucesso de programas governamentais focados na "formação" aligeirada em articulação com outros ministérios além do MEC. Convém registrar que a maioria dos programas tem, no corpo docente, profissionais externos à rede federal, na categoria de bolsistas, cujo vínculo empregatício é precário e temporário. Tal materialidade indica, além da profissionalização relâmpago em bojo, que o número significativo de professores que atua nesses programas não faz parte do corpo permanente da rede federal de Educação Profissional, Científica e Tecnológica. Vislumbramos, no gráfico a seguir, com base nos anuários estatísticos (2013, 2014 e 2015) do IFSC, que há enorme crescimento no número de matrículas em cursos rápidos de Formação Inicial e Continuada (FIC), dentre os quais fazem parte os programas citados anteriormente. 


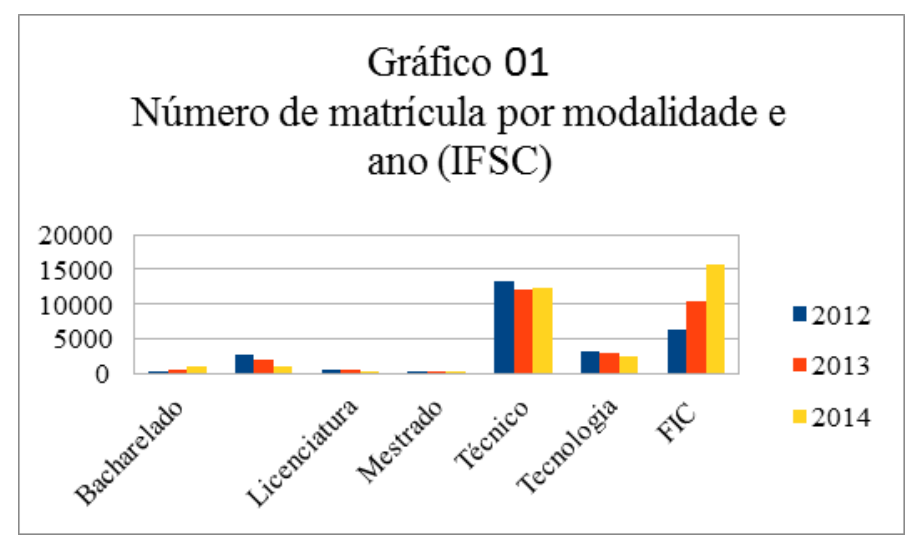

Fonte: Anuário Estatístico IFSC (2013, 2014, 2015). Elaboração própria.

Identificamos, no período de 2012 a 2014, aumento no número de cursos de Formação Inicial e Continuada (FIC), saltando de 6.369 matrículas para a surpreendente marca de 15.652 matrículas, um aumento de 145,75\% e, em paralelo, uma diminuição no número de matrículas nos cursos técnicos regulares de formação plena, o que pode caracterizar o modelo de formação que se pretende. Considerando que o objetivo primeiro dos cursos FIC reside em um tipo de aperfeiçoamento/qualificação cujo nível de escolaridade mínima exigida varia entre ensino fundamental completo a ensino médio completo; a depender da modalidade do curso, com duração média de quatro meses, tal aumento no número de vagas sinaliza claramente para a atuação do IFSC como agência, cuja capilaridade permite, cada vez mais, adentrar na área da assistência social.

Isto porque os cursos FIC destinam-se a um público demandante de políticas que possibilitem, ao menos, a sua permanência nestes cursos, tal é o nível de fragilidade econômica. Trata-se de um público consideravelmente composto por desempregados ou mesmo sem escolaridade, buscando uma qualificação rápida que lhes credencie concorrer no espartano "mercado" de trabalho e sugerindo uma prevalência da certificação em detrimento do processo formativo integral para atuar em profissões regulamentadas por lei.

Com intuito de ajudar na compreensão do amplo público ${ }^{1}$ atendido pelo IFSC, apresentamos indicadores do Anuário Estatístico IFSC 2015 (ano-base 2014). As

\footnotetext{
1 Importante registrar que os estudantes dos programas federais (Mulheres Mil, Sim, PRONATEC Programa Nacional de Acesso ao Ensino Técnico e Emprego) não participam do processo de ingresso mais concorrido do IFSC. A título ilustrativo, em 2016.1, a relação candidato-vaga para ampla concorrência
} 
informações resultaram das respostas aos Questionários Socioeconômicos aplicados pelo Departamento de Ingresso (DEING) aos alunos matriculados na instituição em 2014. No que se refere à renda familiar dos estudantes matriculados em 2014, que participaram dos processos de ingresso mais concorridos, 56\% vive com renda familiar de até 2,5saláriosmínimos. Em relação à ocupação principal dos estudantes, verificamos que há um número razoável de estudantes-trabalhadores empregados na iniciativa privada. Porém, não temos informações sobre condições e formas de inserção no trabalho, não estando no escopo desta pesquisa aprofundar tais questões.

No que tange ao universo familiar, 63\% das famílias é composta de duas a quatro pessoas. Além disso, 40\% das famílias mora de aluguel, casa cedida ou financiada. Em contrapartida, 56\% possui residência própria. Como visto, os estudantes dos cursos regulares do IFSC possuem perfil heterogêneo, proveniente de realidades sociais distintas.

A fim de compreendermos melhor o lócus de nossa pesquisa, encontramos em nota aberta $^{2}$ do Conselho Nacional das Instituições da Rede Federal de Educação Profissional, Científica e Tecnológica (Conif), excerto sobre os sete anos de existência dos atuais Institutos Federais:

Nessa data foram criados 38 Institutos Federais de Educação, Ciência e Tecnologia (IFs) que, em 2015, completam sete anos de educação pública, gratuita e de excelência. Na prática, essas instituições promovem a verticalização do ensino, a pesquisa aplicada, a inovação e a extensão tecnológica, sempre em sintonia com os arranjos produtivos, sociais e culturais locais. (CONIF, 2015, grifos nossos)

Apreendemos, da passagem citada, estreita relação com os ditos "arranjos produtivos", termo costurado para se referir, grosso modo, ao "mercado de trabalho", bem como certo fetiche na relação "inovação" e tecnologia, uma vez que a tal "era tecnológica” pode esconder um conteúdo ideológico. Razão pelo qual “os interessados

chegou a 43 no curso de Engenharia Civil do Campus Florianópolis. Disponível em <http://www.ifsc.edu.br/ensino/modalidade. Acesso em 27 maio 2016.

${ }^{2}$ Publicada em 29 de dezembro de 2015 no site do Conif. Disponível em:< http://portal.conif.org.br/ultimasnoticias/887-institutos-federais-completam-sete-anos.html> Acesso em 06 jan. 2016. 
procuram embriagar a consciência das massas, fazendo-as crer que têm a felicidade de viver nos melhores tempos desfrutados pela humanidade" (PINTO, 2005, p. 41).

O Conif registra ainda que

Com atuação interiorizada e forte política de inclusão social, também são finalidades e características dos institutos federais a oferta da educação profissional e tecnológica em todos os níveis e modalidades do ensino; o desenvolvimento da pesquisa aplicada voltada para a solução de problemas da comunidade; a transferência de tecnologias, além da formação de professores nas áreas de ciências, matemática e para a educação profissional. (grifo nosso)

Destacamos, do trecho anterior, a intensificação da política de “inclusão social” enaltecida pela interiorização/expansão dos Institutos Federais por todo país. A esse respeito, Kuenzer (2010) analisa que a “inclusão social” está amplamente presente nos documentos e textos como objetivo das políticas públicas de educação profissional, o que determina a necessidade de precisar o significado dessa categoria. A autora parte do pressuposto que "no modo de produção capitalista, todas as formas de inclusão são sempre subordinadas, concedidas porque atendem às demandas do processo de acumulação do capital” (p. 254).

Verificamos também o crescimento do status universitário dado aos Institutos Federais, com relativa autonomia devido à sua natureza jurídica de autarquia, equivalente às universidades federais, com reitores eleitos pela comunidade acadêmica. Nesse sentido,

Detentores de autonomia administrativa e didático-pedagógica, os IFs são autarquias vinculadas à Rede Federal de Educação Profissional, Científica e Tecnológica que, atualmente, contabiliza 562 unidades, 56 mil servidores (docentes e técnicos administrativos) e cerca de um milhão de matrículas. Até 2018, há perspectiva de implantação de outros 208 campi em todo o País. (CONIF, 2015, grifos nossos)

Podemos captar o grande processo de expansão vivenciado nos últimos anos pela Rede Federal, bem como sua força de inserção no território nacional. O número de 
unidades, servidores e matrículas cresceu consideravelmente, pois os Institutos Federais surgem com a "missão" de atuar como agência de atenção aos "vulneráveis", fomentando o exército de reserva, administrando conflitos e, desse modo, funcionando como instituição promotora de um determinado capital social que, conforme Motta (2008), diz respeito à capacitação mínima para sobreviver no atual contexto de expropriação capitalista.

O texto do Conif traz ainda um breve resgate histórico dos atuais Institutos Federais,

Apesar de recentes, os institutos federais herdaram a experiência de 106 anos de trajetória da educação profissional no Brasil, cujas atividades tiveram início em 23 de setembro de 1909, quando o então presidente da República Nilo Peçanha criou 19 Escolas de Aprendizes Artífices. Após diversos processos de reordenamento, em 29 de dezembro de 2008, com a publicação da Lei $n^{\circ} 11.892$, o ex-presidente Luiz Inácio Lula da Silva criou os IFs e instituiu a Rede Federal de Educação Profissional, Científica e Tecnológica, hoje composta por 38 Institutos Federais, dois Centros Federais de Educação Tecnológica (Cefet) e o Colégio Pedro II. (CONIF, 2015)

Vale destacar que a lei de criação dos Institutos Federais, Lei $n^{\circ} 11.892$, de 29 de dezembro de 2008 (art. $2^{\circ}$ ), estabelece para as instituições um grande desafio, uma vez que devem atender, a um só tempo, tanto a educação básica, superior e profissional, em suas modalidades presencial e a distância, integrando também a articulação com a educação de jovens e adultos. Como se vê, é imenso e complexo o que se espera dos Institutos Federais. Chama à atenção a oferta educativa em todos os níveis e modalidades, com diferentes itinerários formativos.

Mesmo com pouca ou nenhuma escolaridade anterior, estudantes são "qualificados" profissionalmente nos programas Mulheres Mil e Mulheres Sim (de gênero), cursos FIC atrelados ao PRONATEC ${ }^{3}$, ensejando a base material para o que Kuenzer (2010) diz ser o processo de "inclusão precarizada" ou “inclusão excludente". Nesse sentido, por meio de programas como Mulheres Mil, Mulheres Sim, PRONATEC e cursos rápidos de "qualificação" (FIC), que possuem em média carga horária inferior a

\footnotetext{
${ }^{3}$ Programa Nacional de Acesso ao Ensino Técnico e Emprego.
} 
160 horas, verificamos a face assistencial dos Institutos posta em lei, visto que os interessados nas formações dos Programas Sociais do IFSC são prefeituras, Centros de Referência em Assistência Social (CRAS), Sistema Nacional de Emprego (SINE), Secretarias de Educação, Sindicatos e outros. É o demandante que realiza a pré-matrícula dos interessados nos cursos com aulas voltadas para cidadania, questões de gênero e geração de renda.

Como visto, os Institutos Federais são requisitados para agir como aparelho estatal na tentativa de minimizar mazelas sociais colocadas pelo modo de produção capitalista, apostando na geração de renda pela via do "empreendedorismo". Sobre a temática, Vaz (2013, p. 129-130) afirma que “a Educação tem assumido, progressivamente, papel importante como estratégia política para a redução da pobreza, de maneira que deriva para a assistência social e recupera a ideia 'salvacionista' e 'redentora'”.

\section{A Assistência Estudantil e sua expressão fenomênica no IFSC}

A assistência estudantil no IFSC tem forte relação com a concepção de "inclusão social”, visto que a partir do Plano de Inclusão (2009-2013) a instituição inicia seus trabalhos para a criação de um programa de assistência ao estudante. Assim, em 2009, o IFSC reúne um Grupo de Trabalho (GT) para discutir a proposta junto à comunidade acadêmica. A proposta foi construída tendo por base pesquisas em outras instituições de ensino, estudos sobre referenciais teóricos e o investimento financeiro necessário.

Analisando as políticas de inclusão voltadas à formação dos sujeitos da Educação Especial no IFSC, Rech (2012, p.31) registra que o termo “[... ] 'inclusão social' permeia os discursos e documentos da Rede Federal de Educação. O que podemos perceber sobre a temática é que as ações com esse intuito têm foco nos chamados excluídos, também denominados de minorias sociais". Neste revestimento mais "humanitário" do capital, tanto aqueles com alguma deficiência física ou mental quanto o pobre/“vulnerável" são considerados como sujeitos objetos das políticas de inclusão. O pobre deve ser incluído porque está em desvantagem social e o deficiente deve ser incluído porque é discriminado.

A autora esclarece em sua pesquisa que 
[...] as políticas inclusivas, porém, não se apresentam como uma prática de redução das desigualdades sociais, econômicas e sociais presentes em nosso cotidiano, mas sim como uma nova roupagem do capital, com características mais humanitárias a fim de uma gestão mais aceita pela sociedade e sendo realizada de forma mais participativa, via cooperação, parcerias e participação comunitária nos espaços escolares. (RECH, 2012, p. 138)

Encontramos ainda no plano de inclusão do IFSC a seguinte questão:

Com a implementação de ações inclusivas, o ingresso de pessoas em desvantagem social na Rede Federal de EPT passa a exigir que os demais agentes educacionais sejam preparados para enfrentar os desafios impostos pela condição desses públicos para que o seu acolhimento seja feito de forma tranquila no espaço da instituição. Considerando esse objetivo, bem como a preocupação com o alto índice de evasão, identificado através de pesquisa realizada internamente nos anos 2003, 2004 e 2006, apontou-se a necessidade da criação de um grupo de trabalho que buscasse a adoção de políticas voltadas à permanência e ao êxito do educando. (INSTITUTO, 2009 p. 09, grifo nosso)

Vislumbram-se, então, ações “inclusivas" como estratégia para combater a “evasão", tentando garantir a "permanência” e o "êxito estudantil”. A esse respeito, Stolf (2014, p. 34) nos indica que "a partir de 2003 [...] a questão da permanência estudantil passou a ser tratada como um objeto nas políticas do ensino [...], já que foi desde então que aconteceu a maior expansão de assistência estudantil ocorrida no Brasil até hoje".

Sobre a temática, merecem destaque algumas passagens do Plano de Inclusão do IFSC. Por meio delas, pode-se entender a preocupação com as taxas de evasão, que podem caracterizar o tão alardeado “desperdício de dinheiro público”.

O IFSC toma a decisão de encarar o problema da evasão e fracasso escolar de outra maneira, o da permanência e do êxito do aluno, ou seja, passa a pensar nas possibilidades de manter o aluno na escola antes que ele evada e, ficando ele atinja seus objetivos. (INSTITUTO, 2009, p. 10, grifo nosso) 
No que se refere à repetência, o problema pode estar relacionado a três grandes fatores, a saber: hábitos inadequados de estudo dos alunos; diferentes ritmos de aprendizagem e professores com metodologias e formas de avaliação inadequadas ao público alvo. Sendo assim, para aprofundar e, ao mesmo tempo, reverter esse diagnóstico, estão sendo acompanhadas de forma sistemática algumas ações, tais como: os projetos Hábitos de Estudos no Ensino Médio e monitoria para os alunos; atendimento paralelo aos alunos realizado pelos professores; contrato Pedagógico com alunos. (INSTITUTO, 2009, p.11, grifo nosso)

Outro documento importante para análise da Assistência Estudantil no IFSC é o decreto federal $n^{\circ}$ 7.234/2010, que regulamenta o Programa Nacional de Assistência Estudantil (PNAES). O programa "tem como finalidade ampliar as condições de permanência dos jovens na educação superior pública federal” (BRASIL, 2010). Em seu artigo $4^{\circ}$, consta que "as ações de assistência estudantil serão executadas por instituições federais de ensino superior, abrangendo os Institutos Federais de Educação, Ciência e Tecnologia [...]" (BRASIL, 2010).

Vê-se, portanto, para efeitos da assistência estudantil prevista no decreto, que os Institutos Federais são equiparados às universidades federais. O PNAES prevê ações nas seguintes áreas: moradia estudantil; alimentação; transporte; atenção à saúde; inclusão digital; cultura; esporte; creche; apoio pedagógico; e acesso, participação e aprendizagem de estudantes com deficiência, transtornos globais do desenvolvimento assim como altas habilidades e superdotação. Destacamos, ainda, o artigo $5^{\circ}$ do referido decreto, em que se verifica a seguinte ressalva: "Serão atendidos no âmbito do PNAES prioritariamente estudantes oriundos da rede pública de educação básica ou com renda familiar per capita de até um salário mínimo e meio" (BRASIL, 2010).

Prosseguindo com a análise documental, trazemos um trecho do Documento referência para Assistência Estudantil do IFSC construído no ano de 2010:

São muitos os problemas decorrentes das diferenças sociais, políticas, econômicas, culturais, religiosas, ambientais que demandam por políticas sociais que respondam a estes problemas decorrentes da questão social. Os investimentos no Brasil na área da educação ainda são reduzidos, apesar dos esforços no sentido de ampliá-la, especificamente na esfera pública. (grifo nosso, s.p.) 
Percebemos uma aparente apreensão crítica acerca do fenômeno das desigualdades sociais presentes na contemporaneidade, principalmente quando 0 tratamos como manifestação da "questão social". De acordo com Motta (2008, p. 04), o termo emerge a partir do medo de um setor específico da sociedade que enxerga na pobreza acentuada e generalizada (decorrente do processo de industrialização, da nova organização do trabalho), "o risco ou a 'ameaça de fratura' das instituições sociais existentes $[\ldots] "$...

Logo em seguida, o documento apresenta que,

Com a criação dos Institutos Federais de Educação, Ciência e Tecnologia, em 29 de dezembro de 2008, através da Lei $n^{\circ} 11.892$, ampliam-se as ações e o compromisso com a garantia da igualdade e justiça social. Em consonância com a referida Lei, o Instituto Federal de Educação, Ciência e Tecnologia de Santa Catarina, cuja missão é "desenvolver e difundir conhecimento científico e tecnológico, formando indivíduos capacitados para o exercício da cidadania e da profissão", estabelece em documentos normativos as diretrizes para inclusão social por meio de sua intervenção. (BRASIL, 2010, grifo nosso)

Novamente, aparece a expressão "inclusão social” como garantia da igualdade e justiça social, acreditando que ações focalizadas sejam capazes de tal feito. Há a tentativa de minimizar os problemas decorrentes das desigualdades sociais a partir da perspectiva “inclusiva”. Porém, a garantia plena de igualdade e justiça social está muito além dos muros institucionais. As injustiças e desigualdades sociais, sob os moldes atuais, perpassam uma complexa rede de determinações sociais que são impossíveis de se superar, a menos que se destitua a relação Capital, Estado e Trabalho alienado (MÉSZÁROS, 2002) presentes na sociedade. Acreditamos que uma educação crítica pautada pela resistência contra-hegemônica, que vise à superação do conformismo, pode contribuir para o processo de emancipação social, para além da lógica expropriadora do capital.

Avançando em nossa análise, destacamos que o documento referência para a Assistência Estudantil no IFSC propõe uma série de ações a fim de ampliar as condições de acesso e "permanência com êxito" dos estudantes na Instituição. Uma das ações 
propostas foi a de criação, reestruturação e ampliação de programas de assistência estudantil.

Ainda em 2010, temos a aprovação da Resolução $n^{\circ}$ 001, que regulamenta a Assistência Estudantil do IFSC. Em seu artigo $2^{\circ}$, a normativa interna enaltece que a "Assistência Estudantil objetiva garantir condições de acesso e permanência com êxito dos estudantes no percurso formativo". (INSTITUTO, 2010a). Logo em seguida, no artigo $3^{\circ}$, são apresentados os princípios da Assistência Estudantil, conforme segue:

I- supremacia do atendimento às necessidades socioeconômicas e pedagógicas; II- universalização da assistência ao estudante; III- respeito à dignidade do sujeito, à sua autonomia e ao seu direito a benefícios e serviços de qualidade, bem como à convivência escolar e comunitária; IVigualdade de direito no acesso ao atendimento, sem discriminação de qualquer natureza; $V$ - equidade na atenção, visando a redução da desigualdade; VI- divulgação ampla dos benefícios, serviços, programas e projetos, bem como dos recursos oferecidos pela instituição e dos critérios para seu acesso; VII- participação da comunidade acadêmica nos processos decisórios. (INSTITUTO, 2010a, grifo nosso)

O artigo $5^{\circ}$ da resolução registra que as ações e programas da Assistência Estudantil a serem implementados dividem-se em duas formas de atendimento: IAtendimento universal aos estudantes (Programa de Saúde e Apoio Psicossocial, Programa de Alimentação Estudantil, Programa de Atendimento aos Filhos dos Estudantes, Programa de Moradia Estudantil, etc.); Il- Atendimento aos estudantes em vulnerabilidade social.

No que se refere ao termo estudante em "vulnerabilidade social”, a resolução conceitua "[...] como processos de exclusão, discriminação ou enfraquecimento dos grupos sociais e sua capacidade de reação, como situação decorrente da pobreza, privação e/ou fragilização de vínculos afetivo-relacionais e de pertencimento social". Além disso, estabelece que a Assistência Estudantil no IFSC será gerida por um Comitê Gestor, vinculado à Pró-Reitoria de Ensino, com recurso da Ação Assistência ao Educando da Educação Profissional. 
Por entendermos que a construção de documentos da política educacional não ocorre de maneira harmônica, mas permeada por disputas, foi feito um levantamento nas atas das reuniões do Conselho Superior do IFSC (período de 2011 a 2015) a fim de identificar elementos que nos ajudassem na compreensão da Assistência Estudantil na instituição.

Na ata CONSUP ${ }^{4}$ de maio de 2012 aparece a proposta de incluir, dentre os assuntos a serem discutidos naquele ano, a temática da assistência estudantil. Em 2013, no mês de fevereiro, na primeira reunião ordinária do ano, encontra-se em evidência a apresentação da reestruturação da Pró-Reitoria de Ensino e a Diretoria de Assuntos Estudantis (DAE):

O Assessor de Assuntos Estudantis [...] explicou que o principal objetivo da Diretoria de Assuntos Estudantis - DAE é trabalhar em tudo o que envolve o aluno. Hoje o IFSC tem uma diversidade de cursos e de público e está desenvolvendo diversos programas de inclusão social, entretanto existem muitos cursos com taxa de conclusão baixa e com taxa de evasão altíssima. O IFSC precisa criar as políticas institucionais e as coordenadorias específicas para estabelecer um fluxo de trabalho entre a PROEN e os câmpus.

Vislumbra-se, portanto, que a criação da Diretoria de Assuntos Estudantis (DAE) acontece em um momento ímpar para a instituição, que vê aumentar suas responsabilidades decorrentes do processo de expansão e nova institucionalidade, com demandas para atuar em programas do governo federal pautados pela “inclusão social”. Na mesma reunião, o Diretor de Desenvolvimento de Ensino do IFSC destaca que

[...] essa nova estrutura da PROEN é uma estratégia de atuação e suporte para que o aluno venha para o IFSC, permaneça e seja certificado pela sua competência, e para mostrar para a sociedade qual é o papel da instituição. [...] a SETEC estabelece as diretrizes e as metas a serem atingidas, entre elas está o índice de $90 \%$ de permanência, 10\% de oferta PROEJA, 20 alunos por professor.

\footnotetext{
${ }^{4}$ Conselho Superior.
} 
A fala transcrita acima vem ao encontro do que alerta Algebaile (2004). A autora argumenta que a escola pública acaba sendo usada como algo semelhante a um posto avançado do Estado, permitindo certas condições de controle populacional e territorial, novos canais de negociação do poder em diferentes escalas e certa "economia de presença" em outros âmbitos da vida social, particularmente na política social.

Em leitura do Plano de Desenvolvimento Institucional (PDI, 2014) do IFSC, referente ao quadriênio 2015-2019, encontramos em seu segundo capítulo o Plano Pedagógico Institucional (PPI). Nele estão presentes elementos importantes a respeito da assistência estudantil, a saber:

Para garantir a permanência e o êxito do discente nos cursos, estão sendo implementados programas de assistência estudantil desde 2011. Um deles concede apoio financeiro para discentes em situação de vulnerabilidade social. Esse auxílio financeiro tem por objetivo manter na instituição os discentes propensos a abandonar os cursos por falta de condições financeiras para necessidades básicas, tais como alimentação, transporte e material didático. (INSTITUTO, 2014a, p. 60-61)

Encontramos nesse PDI (2015-2019) a base material que enseja reflexões para o debate sobre o Programa de Atendimento ao Estudante em Vulnerabilidade Social (PAEVS), com seus condicionantes e processos subjacentes. Com a intenção de construir uma análise que permita entender as relações que perpassam o Programa PAEVS, selecionamos documentos do período de 2011 a 2015 encontrados no sítio eletrônico da instituição, para que, examinando-os, consigamos apontar suas determinações. O recorte temporal se justifica por ocorrer, nesse período, o surgimento e a consolidação do PAEVS no IFSC.

No que se refere aos editais de concessão, identificamos, no ano de 2012, a publicação do primeiro edital unificado de oferta do Programa PAEVS. Porém, os programas focalizados para atendimento aos estudantes em "vulnerabilidade social” iniciam em 20115. A partir da leitura dos editais, evidenciamos que é estabelecido o período de seis meses para o estudante, beneficiado por algum edital, realizar renovação

\footnotetext{
${ }^{5}$ Até a finalização da presente pesquisa, não havia edital disponibilizado no sítio eletrônico do IFSC sobre as "regras" para concessão do auxílio do PAEVS para o ano de 2011.
} 
do seu auxílio com assinatura de um termo de compromisso junto à instituição. Além disso, a cada período de 12 meses de vínculo com o programa, há o processo de reavaliação, a fim de verificar se houve mudança na condição socioeconômica do estudante. Nesse caso, realiza-se uma espécie de "nova inscrição" com entrega de toda documentação comprobatória exigida em edital. O processo de análise socioeconômica do programa é realizado por assistente social vinculado às coordenadorias pedagógicas dos campi.

Pudemos verificar que, ao longo da existência do programa, criaram-se alguns procedimentos para concessão do auxílio financeiro. Em 2012, o estudante deveria preencher questionário socioeconômico online e entregar a documentação comprobatória de sua condição no ato da inscrição. Os documentos necessários eram: documentos pessoais de todos os membros da família, comprovação de renda familiar e comprovação de agravantes sociais (originais e cópias). Em todos os editais de concessão, identificamos que o recebimento dos auxílios se ordenou pela condição de "vulnerabilidade social" do estudante até o limite de disponibilidade orçamentária do IFSC. Esses montantes foram crescendo ao longo do período, chegando a cerca de nove milhões em 2016.

A partir de 2013, aparece um elemento novo no PAEVS. Na disposição final dos editais, há o esclarecimento sobre a garantia de sigilo a respeito das documentações e informações prestadas, uma vez que a instituição possui, praticamente, uma 'anamnese social' da família do estudante contemplado. No ano de 2014, o Conselho Superior do IFSC aprova a Resolução $n^{\circ} 47$, que regulamenta o PAEVS. A referida normativa conceitua "vulnerabilidade social” como “[...] processos de exclusão, discriminação ou enfraquecimento dos grupos sociais e sua capacidade de reação, como situação decorrente da pobreza, privação e/ou fragilização de vínculos afetivo-relacionais e de pertencimento social".

Destacamos, a seguir, artigos da Resolução 47/2014, que regulamenta o PAEVS, para ajudar na compreensão da lógica implementada:

Art. $2^{\circ} \mathrm{O}$ Programa de Atendimento ao Estudante em Vulnerabilidade Social destina-se ao estudante com dificuldade de prover as condições 
necessárias para a permanência e o êxito durante o percurso escolar. A permanência do estudante na instituição compreende o tempo definido em cada projeto de curso para a integralização da carga horária prevista nesse projeto, incluindo o estágio supervisionado, quando previsto. $O$ êxito ocorre quando o estudante integraliza essas unidades curriculares, passando a ter direito à certificação.

Art. $3^{\circ} \mathrm{O}$ Programa de Atendimento ao Estudante em Vulnerabilidade Social é destinado ao estudante matriculado em cursos presenciais: FIC com no mínimo 160 horas ou com duração mínima de 04 meses; Mulheres Sim; PROEJA; Integrado; Concomitante; Subsequente; Graduação e Pós-graduação com renda bruta per capita de até 1 1/2 salário mínimo vigente e caracteriza-se pela concessão de auxílio financeiro em forma de pecúnia [...]. $\S 1^{\circ} \mathrm{O}$ estudante matriculado em curso de pósgraduação será atendido pelo Programa de Atendimento ao Estudante em Vulnerabilidade Social, após todos os outros cursos, conforme disponibilidade orçamentária.

No que se refere às condições para acessar e permanecer no PAEVS, encontramos nos artigos $4^{\circ}$ e $5^{\circ}$ as especificidades:

Art. $4^{\circ}$ São condições de acesso ao Programa de Atendimento ao Estudante em Vulnerabilidade Social: I - Matrícula regular; II - Índice de Vulnerabilidade Social validado por assistente social, confirmando sua condição vulnerável. (grifo nosso)

Art. $5^{\circ}$ São condições para permanência no Programa de Atendimento ao Estudante em Vulnerabilidade Social: I - Matrícula regular; II - Frequência regular (75\%); III - Participação em atividades programadas pelo setor responsável pela Assistência Estudantil do câmpus; IV Comprometimento com os estudos a ser avaliado através do envolvimento do estudante com o ambiente acadêmico, por meio de sua assiduidade, empenho e iniciativa para a aprendizagem, não sendo considerada somente a aprovação. (grifo nosso)

Com base nessa materialidade, partimos do pressuposto que o PAEVS é estratégia importante do IFSC para reduzir os altos índices de evasão nos cursos. A instituição precisa cumprir metas estabelecidas pelo governo federal em relação à permanência estudantil para ter liberação integral de seus recursos financeiros. Nesse sentido, se o estudante não concluir o curso, há perda orçamentária, o que pode precarizar os trabalhos de ensino, pesquisa e extensão. Compreendemos que, por meio do 
estratagema “permanência e êxito", o Ministério da Educação (seguindo pressupostos de agências internacionais) dá o tom das "negociações".

Apreendemos que o slogan 6 "permanência e êxito" constitui instrumento de gestão e controle de gastos públicos, com o condicionante de retorno para o Estado em relação ao investimento realizado. É exigido, então, resultado produtivo da educação. Dessa forma, o processo educacional vem tornando-se recurso de coesão social e implementação do desenvolvimento econômico requerido, mesmo alicerçado em estruturas com enormes desigualdades sociais.

A partir da resolução e dos editais de 2015, identificamos ainda que, para que o auxílio financeiro do PAEVS fosse concedido, o IFSC implementou uma nova racionalidade instrumental de trabalho, criando o Índice de Vulnerabilidade Social (IVS) do estudante, composto de variáveis reunidas que definem a situação social do discente. O IVS envolve análise de documentos e questionário socioeconômico e, se necessário, entrevista. A devolução do IVS ao estudante é realizada em até 30 dias corridos da data da solicitação, tendo validade por um ano. No quadro adiante, apresentamos em detalhes as variáveis que compõem o IVS.

Quadro 01: Composição do Índice de Vulnerabilidade Social (IVS)

\begin{tabular}{|c|l|}
\hline VARIÁVEL & \multicolumn{1}{c|}{ CONCEITO } \\
\hline Renda bruta per capita familiar & $\begin{array}{l}\text { É a soma da totalidade dos rendimentos obtidos pela unidade } \\
\text { familiar, incluso o estudante, dividida pelo número de membros da } \\
\text { unidade familiar. A renda bruta é composta pelo último mês do } \\
\text { valor bruto de salários, proventos, gratificações eventuais, etc. }\end{array}$ \\
\hline $\begin{array}{c}\text { Ocupação, Trabalho e Emprego por } \\
\text { membro da família }\end{array}$ & $\begin{array}{l}\text { Presença ou não de vínculo empregatício, condição de trabalhador } \\
\text { autônomo ou informal. }\end{array}$ \\
\hline $\begin{array}{c}\text { Situação patrimonial familiar } \\
\text { Moradia do estudante }\end{array}$ & $\begin{array}{l}\text { Propriedades móveis, imóveis, sejam de pessoas físicas ou jurídicas, } \\
\text { por exemplo: apartamentos, casas, salas comerciais, depósitos em } \\
\text { poupança, carro, motocicletas, participações em sociedade, quotas } \\
\text { de empresas, máquinas agrícolas e benfeitorias agrícolas, aplicações } \\
\text { financeiras, etc. }\end{array}$ \\
\hline Saúde por membro da família & $\begin{array}{l}\text { Tipo da moradia, situação de moradia, tipo de localidade, área de } \\
\text { risco. }\end{array}$ \\
\hline Transporte do estudante & $\begin{array}{l}\text { Presça de doença, necessidades específicas, dependência química } \\
\text { e acesso a sistema de saúde por convênio particular. }\end{array}$ \\
\hline a residência e o campus do IFSC em que está matriculado,
\end{tabular}

\footnotetext{
6 Por slogan se entende expressão concisa, fácil de lembrar, utilizada em campanhas políticas, de
} publicidade, de propaganda, para lançar um produto, marca etc. 


\begin{tabular}{|c|l|}
\hline & mensurado pela distância entre estes dois pontos. \\
\hline $\begin{array}{c}\text { Acesso à educação do estudante e } \\
\text { por membro familiar }\end{array}$ & $\begin{array}{l}\text { Origem escolar do estudante, a escolaridade do estudante. Para } \\
\text { membro da família será considerado o vínculo com estabelecimento } \\
\text { de ensino formal privado (bolsista parcial e financiamento } \\
\text { estudantil), exceto para pós-graduação. }\end{array}$ \\
\hline $\begin{array}{c}\text { Composição familiar (se possui } \\
\text { idosos, crianças, adolescentes, } \\
\text { pessoa em restrição de liberdade, } \\
\text { etc.) }\end{array}$ & $\begin{array}{l}\text { Família é a unidade nuclear composta por uma ou mais pessoas, } \\
\text { eventualmente ampliada por outras pessoas que contribuam para o } \\
\text { rendimento ou tenham suas despesas atendidas por aquela unidade } \\
\text { familiar. }\end{array}$ \\
\hline Participação em programas sociais & $\begin{array}{l}\text { Recebimento de auxílio financeiro, por meio de programas sociais } \\
\text { das esferas federal, estadual e municipal, pelo estudante ou outro } \\
\text { membro do grupo familiar. }\end{array}$ \\
\hline Ingresso por cotas & Ingresso no IFSC pelo sistema de cotas, conforme legislação. \\
\hline
\end{tabular}

Fonte: Resolução CONSUP /IFSC Nº 47/2014. Elaboração própria.

Tendo em vista que a construção de documentos da política educacional se dá em meio a contradições, verificamos na ata da 4 a reunião ordinária do CONSUP/IFSC, de 2013, que

O conselheiro [...] questionou sobre os critérios de concessão do auxílio vulnerabilidade, ou seja, que tipo de aluno é contemplado com o benefício. Alguns conselheiros declararam que há casos de distorção da concessão do benefício nos câmpus. Outros conselheiros relataram que a seleção é feita conforme os documentos apresentados e que o processo é recente, está em implantação, e em alguns câmpus está funcionando bem. Mas argumentaram que é necessário um acompanhamento direto dos gestores e dos servidores envolvidos para garantir a eficiência do programa. O Diretor de Assuntos Estudantis [...] informou que é difícil ter controle total da situação. Destacou que para participar do programa de assistência estudantil, o aluno entrega a documentação exigida e os servidores fazem a análise documental para a concessão e depois o acompanhamento. Explicou que já houve casos de denúncia e se confirmados os alunos deixam de receber o benefício. A conselheira [...] informou que o grupo de servidores que atua na área está tentando compor a política de assistência estudantil na instituição e está fazendo o possível para melhorar, e destacou que o programa não deve ser avaliado pela exceção, ou seja, aqueles que recebem o benefício de forma errada, mas sim pela realidade dos alunos que precisam e estão sendo atendidos. A conselheira [...] relatou que o IFSC foi ousado em 2010 em querer ter uma política de assistência estudantil na instituição, mas representou um avanço em termos de reconhecer a assistência estudantil como um direito do aluno: a instituição além de dar oportunidade de acesso precisa dar condições para a continuidade da formação. Destacou que os casos específicos devem ser denunciados[...]. Ressaltou que o IFSC avançou muito e está trabalhando para ser mais eficiente e os problemas não são justificativas para retroceder. (grifo nosso) 
Conforme excerto, a "eficiência" e a lógica de transparência formal do programa aparecem como preocupação da instituição. A administração gerencial do serviço prestado pela assistência estudantil assume, então, o centro das discussões. Por fim, encontramos na ata da $33^{\mathrm{a}}$ reunião ordinária do CONSUP, de 17 de dezembro de 2014, o debate sobre as alterações a serem colocadas em prática no PAEVS em 2015:

[...] a regulamentação propõe criar o IVS - Índice de Vulnerabilidade Social, que será determinado a partir de um questionário respondido pelos alunos, que contempla outros aspectos importantes que hoje não são considerados. Hoje a análise de vulnerabilidade social é feita quando os alunos participam dos editais, tendo que aguardar os períodos de inscrição. A nova regra propõe que os alunos solicitem a qualquer tempo a análise do IVS na Coordenadoria Pedagógica, que será realizada pelas assistentes sociais, e somente aqueles que tenham o IVS determinado possam participar dos editais. [... ] foi sugerido alterar no art. $5^{\circ}$ o termo "comprometimento escolar" por "rendimento escolar", porém argumentou-se que esse aspecto é muito complexo e foi bastante debatido no grupo, chegando-se ao consenso de que se for exigido um rendimento escolar e o aluno não atingir, corre-se o risco de deixar de dar apoio aos que realmente precisam. (grifo nosso)

Apreendemos que o objetivo maior do processo do PAEVS centra-se na permanência do estudante na instituição. A questão do êxito fica em segundo plano, considerando que as exigências de rendimento estudantil no IFSC são altas e, por isso, julgada uma instituição com "ensino forte", com docentes que não aceitam o processo de aprovação sem a devida "meritocracia". Assim, condicionar o Programa ao desempenho seria muito arriscado, na visão dos conselheiros.

\section{Reflexões para o debate}

Identificamos na análise documental posta em movimento, que o Programa de Assistência Estudantil PAEVS aparece ligado ao slogan "permanência e êxito", sendo alicerçado pela concepção de "inclusão social”. Garcia (2004), ao pesquisar detidamente tal conceito e suas políticas subjacentes, identifica que as políticas inclusivas almejam a harmonização social via discursos de coesão, solidariedade e pertencimento, mesmo que 
as desigualdades sociais permaneçam. A noção da "reforma" defendida nas políticas e programas pautados na inclusão social, sugere que se faz necessário remanejar algo mal gestado, disseminando as vantagens de uma educação que não exclui e não classifica, mas prioriza as necessidades de aprendizagem. (GARCIA, 2004).

Frigotto (2010, p. 419) adverte que "o risco do uso abusivo desta noção [in/exclusão] situa-se na possibilidade de fixar-nos no sintoma e nas consequências das formas que assumem as relações sociais capitalistas hoje", o que pode nos encaminhar “[...] no plano das políticas, a uma postura reformista e conservadora” (p. 419). Conforme o autor, "não se trata de não reconhecer a importância e a necessidade das políticas de inclusão, mas de atentar [...] que a questão social vem sendo trazida [...] para a 'margem"' (p. 423).

Nessa esteira, considerando a crise estrutural do capital, compreende-se que não são suficientes as políticas de inclusão (cada vez mais precárias), se levarmos em conta o momento histórico pelo qual passamos, em que se prolifera a inserção subalterna informal sob a nomeação de "trabalho autônomo" ou empreendedorismo (FRIGOTTO, 2010).

Silva (2012) provoca alguns questionamentos sobre a chamada inclusão social; segundo a autora, "[...] um debate que tem se mostrado caro aos estudiosos das questões sociais na contemporaneidade" (p. 72). Ela entende que "[...] é com esse mote que programas, projetos e toda sorte de intervenções na atual conjuntura da sociedade têm sido erigidos" (p. 72). Além disso, registra que a ideia de "inclusão" vem ganhando espaço no meio empresarial, passando pelas políticas públicas educacionais e mídias. O conceito está presente em diferentes situações, não havendo precisão em seu uso.

A autora argumenta também que o termo inclusão está diretamente relacionado às contradições intrínsecas da sociabilidade do capital. A inclusão social e as políticas relacionadas, portanto, carecem de investigações em essência, tentando captar "o que quer[em] negar ao revelar e o que revela[m] quando nega[m]" (p. 76). Nesse sentido, 
[...] o efeito da política liberal de inclusão, em que ao comprovar, apontar e aceitar a existência da condição de excluído, o estado de risco social, induz a pensar que se reconheço, logo socorro. No nível mais elementar, isso apela para nosso altruísmo e sentimento de preocupação com o próximo, forjando o conforto de que vivemos em tempos em que as injustiças sociais estão sendo revistas e as políticas sociais aperfeiçoadas, dentre as quais àquelas relativas aos jovens pobres. (SILVA, 2012, p. 76-77, grifo no original)

Pela via do consenso, ao se identificar o "sujeito excluído", reconhecemos a necessidade de inclusão. Assim, Silva (2012, p. 78) questiona: "a que interessa as atuais políticas de inclusão nos termos em que estão formuladas se não para a manutenção da ordem capitalista?". A ideia de inclusão/exclusão é central nos programas sociais, sendo um fenômeno a ser apreendido. Com referencial analítico semelhante, Rech (2012) argumenta:

O papel de amenizar as desigualdades sociais parece ser aceito e tomado como princípio dentro da Rede Federal, tomando para si o papel de promotor de igualdade social e de obtenção de cidadania. Sobre esse "enfrentamento" às desvantagens sociais, a inclusão se apresenta como papel crucial e podemos problematizar, inclusive, que os documentos levam ao entendimento de que somente através da inclusão poder-se-á tornar nossa sociedade mais justa. (RECH, 2012, p. 159)

Com fundamento em Motta (2007), temos que o Programa PAEVS é posto em prática por instituição que faz parte do aparelho hegemônico do Estado, refletindo em despolitização e conformismo social. Pela via da educação para o capital humano, e tendo em vista a necessidade de coesão/harmonização requerida para expandir a ideologia dominante, compreendemos que por meio do PAEVS são administradas as desigualdades sociais mais extremas que surgem no instituto. Sua atuação cumpre papel estratégico de fortalecimento da ideologia do capital social, visto que a expansão predatória do capital precisa de instrumentos capazes de naturalizar sua perpetuação e tornar toleráveis suas fissuras mais extremas.

Neste horizonte, ao refletir sobre programas focalizados como o PAEVS, Frigotto (2010, p. 438) coloca que 
[...] a tarefa política é, sem dúvida, transcender às estratégias de inclusão degradada, sob programas focalizados e de caridade social que funcionam como alívio à pobreza e manutenção do status quo. Para ir além do focal, a luta da classe trabalhadora e dos movimentos que o constituem implica [...] redefinir o papel do Estado. Não do Estado em sua função de preposto para o capital, mas [...] de um Estado radicalmente democrático. Aqui a tarefa é criar capacidade política para ter controle do fundo público e sua aplicação para garantir os múltiplos direitos e necessidades humanas e não as exigências do capital. Esta possibilidade está condicionada, sem dúvida, à organização, cada vez mais ampla, da classe trabalhadora em seus diferentes organismos coletivos e nos movimentos sociais. (grifo nosso)

Nessa perspectiva, segundo o autor, a relação in/exclusão constitui “[...] sintoma de relações sociais, estrutural e organicamente, geradoras da desigualdade. Relações que precisam ser rompidas e superadas. Esta travessia implica teoria densa e ação política organizada" (FRIGOTTO, 2010, p. 439).

Indo ao encontro das reflexões críticas presentes no balanço desta pesquisa sobre a Assistência Estudantil, afirmamos que, em tempos de valorização das políticas neoliberais, o PAEVS é pautado essencialmente pela lógica de serviço e não de direito. Isso traz à tona sua instabilidade, que ora garante a "permanência" do aluno e ora o exclui devido a inúmeros aspectos que condicionam o recebimento e continuidade dos benefícios, pois não há como contemplar a todos.

Compreendemos que a retórica da "permanência" apregoada pelo PAEVS traz consigo a ideia de desenvolvimento de país difundida pelas políticas públicas contemporâneas. Nesse sentido, espera-se que as pessoas consigam se "qualificar" minimamente para atender as exigências do expropriador "mercado de trabalho", sendo incluídas subalternamente em tal dinâmica. A educação aparece, nesse ínterim, como gestora responsável pela diminuição dos efeitos da pobreza extrema, oferecendo condições mínimas para que os indivíduos possam ser considerados "empregáveis". Acomodam-se as desigualdades sociais via despolitização da classe trabalhadora, a grande prejudicada estruturalmente com os auxílios provenientes das políticas focalizadas de cariz neoliberal.

A sociabilidade do capital é complexa, o que facilita o encobrimento de seus próprios mecanismos predatórios. Tem-se, portanto, a impressão de que o Estado está 
trabalhando arduamente (via políticas de "inclusão, acesso e permanência" na educação) para eliminação das desigualdades sociais. Porém, as ações focais e seus programas se constituem, paradoxalmente, em alimento que contém elementos nocivos, atuando como mal necessário quando consideramos a urgência de sobreviver.

Nessa linha, cabe enfatizar o horizonte adotado por esta pesquisa, que vem ao encontro do que analisa Leite (2012):

Não se pode perder de vista que uma parte importante dessas novas formas para atender o social - e amortecer e neutralizar as expressões da "questão social" - são, na verdade, instrumentos para eliminar o caráter da luta política, convertendo os conflitos e tensões sociais em expressões vazias de sentido transformador, com a intencionalidade de convertê-las em expressões neutras. As políticas sociais, travestidas doravante em "programas", funcionam exatamente como recurso para divisão das classes, a partir da sua característica residual. Perde-se, com isso, o horizonte da luta coletiva. Ademais, despolitiza as políticas sociais, tirando o foco da totalidade do real, naturalizando, banalizando e - ato contínuo - criminalizando as refrações da "questão social", transformando-as em expressões individuais. (LEITE, 2012, p. 469-470)

Reafirmamos que o PAEVS se destina a tratar os sintomas das desigualdades sociais que chegam ao IFSC. A ajuda aparente contribui, contraditoriamente, para maquiar as mazelas sociais de parcela significativa de estudantes da instituição. Em que pese o cumprimento das exigências governamentais para "permanência e êxito", o estudante que não teve educação básica/elementar de qualidade, encontra no instituto uma realidade que, dada as exigências colocadas, impulsiona-o para a não continuidade dos estudos. Nessa perspectiva, a tão propalada "inclusão social” trilha a contramão do que anuncia, visto que "[...] as diferenças são convertidas em desigualdades como um pretexto para a exploração" (MIRANDA, 2009, p. 33), assim forjando sua legitimidade. 


\section{Considerações finais}

$\mathrm{Na}$ investigação desenvolvida, analisamos a Assistência Estudantil no IFSC por meio do Programa de Atendimento ao Estudante em Vulnerabilidade Social (PAEVS). O programa, central na política de assistência da instituição, teve início no ano de 2011, sendo regulamentado posteriormente pela Resolução CONSUP $n^{\circ} 47 / 2014$, integrando a política institucional do IFSC para "permanência e êxito" acadêmico, em que um auxílio financeiro é concedido ao estudante considerado em "vulnerabilidade social”.

No processo de pesquisa, partimos do pressuposto de que os problemas sociais que adentram o IFSC, na atualidade, têm relação direta com o cenário da crise estrutural do capital. Evidenciamos por meio da análise documental que o PAEVS, na medida em que não problematiza o caráter de desigualdade estrutural da sociedade, "cronifica-se" como programa emergencial e assistencialista que retroalimenta o capital. Assim, nocivo em atuar como armadilha ideológica, obscurecendo a realidade por se caracterizar como sendo sempre positivo.

A partir da materialidade colocada em movimento, identificamos que o programa, além de possuir caráter focalizado, atua em nível estratégico para solucionar problemas de "permanência” e "êxito" estudantil. Por sua atuação no tratamento compensatório dos efeitos da pobreza, acaba funcionando como instrumento que dissocia as desigualdades sociais de seus determinantes estruturais, visto que suas ações se limitam a aspectos conjunturais que chegam ao IFSC.

Também demonstramos a conexão existente entre os termos "permanência" e "êxito" costurados pelo programa PAEVS com o atual contexto socioeconômico, em que há forte pressão estatal, via $\mathrm{MEC}^{7}$ e $\mathrm{SETEC}^{8}$, por cobrança de resultados e enxugamento dos gastos públicos, uma vez que consideram "evasão" e "repetência” como prejuízo do Estado em seus investimentos. A grande apreensão com as taxas de "permanência" e “êxito" não revela a essência do fenômeno, o qual, em nossa análise, relaciona-se fortemente com o processo de financiamento da educação e sua transformação em mercadoria com características próprias do capitalismo contemporâneo. A instituição se vê coagida ao cumprimento de metas de permanência para ter acesso integral aos

\footnotetext{
${ }^{7}$ Ministério da Educação.

${ }^{8}$ Secretaria de Educação Profissional e Tecnológica vinculada ao Ministério da Educação.
} 
recursos financeiros. Portanto, caso o índice de evasão seja alto, ocorre perda orçamentária, podendo prejudicar o ensino, pesquisa e extensão. Nesse horizonte, a "eficiência" do PAEVS é motivo de preocupação para a instituição. Dadas as exigências colocadas externamente, o sucesso da gerência da assistência estudantil avulta no centro das discussões.

Identificamos que o IFSC, na atual conjuntura, encontra-se atrelado ao sucesso de programas governamentais focados na "formação" profissional aligeirada, com forte disseminação do slogan “inclusão social”. É, nesse sentido, complexo o que se requer dos Institutos Federais e do IFSC em específico, com obrigação de "qualificar" profissionalmente em curtíssimos períodos, via programas relâmpagos, forjando a base do que Kuenzer (2010) denomina ser o processo de "inclusão excludente". Assim, reforçamos o movimento assistencial dos Institutos, uma vez que atuam como aparelho estatal para tratar as mazelas sociais advindas da sociabilidade expropriadora, em vigência na contemporaneidade.

Nossa investigação mostrou que o PAEVS aparece alicerçado na ideia de "inclusão social" como mecanismo de justiça e igualdade social. Os autores (GARCIA, 2004; FRIGOTTO, 2010; SILVA, 2012) refletem sobre as contradições e usos naturalizados do binômio exclusão/inclusão, uma vez que este enfoca somente as consequências das relações sociais capitalistas. Assim, é urgente perceber que a questão social aparece reduzida a um problema operacional, sendo colocada constantemente à margem das relações estruturais que a produziram.

Nessa esteira, com referência em Frigotto (2010) e Motta (2007), se considerarmos o atual contexto histórico, com crise estrutural do trabalho, compreendemos que não são suficientes políticas de inclusão, como a enaltecida pelo PAEVS, uma vez que vêm ao encontro da despolitização e do conformismo social, cumprindo papel essencial para fortalecer a ideologia do “capital social”. A esse respeito, Leite (2012, p. 469) afirma que programas focais colocados para atender demandas sociais são "[...] instrumentos para eliminar o caráter da luta política, convertendo os conflitos e tensões sociais em expressões vazias de sentido transformador, com a intencionalidade de convertê-las em expressões neutras".

Enfatizamos que o slogan da "permanência e êxito" difundido pelo PAEVS se 
relaciona com a noção de desenvolvimento presente nas políticas neoliberais. Almeja-se, nesse cenário, que seja possível "qualificar-se" minimamente para suprir as carências do “mercado de trabalho”. Grande parcela da sociedade, nesse horizonte, é incluída precariamente nesse universo, no qual a educação é colocada como panaceia para as desigualdades gestadas pela sociabilidade do capital.

Deste modo, ao tratar os sintomas das desigualdades sociais que chegam ao IFSC, o programa PAEVS é mais um elemento a compor o adiamento dos "embates" necessários para a mudança social requerida, pois, considerando a totalidade social, os programas focados em públicos estratégicos ajudam a retroalimentar, em essência, a própria expropriação daqueles que sobrevivem da venda de sua força de trabalho. Sobre o assunto, Vaz (2013) inspira-nos a buscar outra realidade possível, em que “[...] a disputa pelo projeto de uma educação pautada para além do capital deve prevalecer como presença e horizonte da luta da classe trabalhadora" (p. 131).

Registramos que o entendimento e a compreensão dos processos que ficam ocultos nos programas e políticas educacionais podem contribuir para "transcender às estratégias de inclusão degradada" (FRIGOTTO, 2010, p. 438), acenando para um horizonte em que a capacidade política possa vencer a batalha contra as necessidades do capital, com oxigenação e organização dos movimentos sociais na busca pela igualdade substantiva que, conforme Mészáros (2015) é um princípio orientador em oposição ao princípio da igualdade formal (neo) liberal. Sob as condições atuais, o autor registra que a igualdade real ou substantiva deve ser recolocada e vislumbrada, sendo necessária para se estabelecer um mecanismo alternativo, para além da lógica de produção expropriadora do capital.

Por fim, apontamos para a importância de se realizar futuras pesquisas envolvendo programas educacionais de Assistência Estudantil. A esse respeito, colocamos como sugestão a necessidade de avaliar as implicações do programa PAEVS entre os egressos do IFSC. 


\section{Referências}

ALGEBAILE, Eveline Bertino. Escola pública e pobreza: expansão escolar e formação da escola dos pobres no Brasil. 2004. Tese (Doutorado em Educação) - Universidade Federal Fluminense, Niterói/RJ, 2004.

BRASIL. Decreto ${ }^{\circ}$ 7.234, de 19 de julho de 2010. Dispõe sobre o Programa Nacional de Assistência Estudantil (PNAES). Disponível em:

<http://www.planalto.gov.br/ccivil_03/_Ato2007-2010/2010/Decreto/D7234.htm>. Acesso em 20 dez. 2015.

BEHRING, Elaine Rossetti. Política social: fundamentos e história. 9 ed. São Paulo: Cortez, 2011.

CIAVATTA, Maria. Universidades Tecnológicas: horizontes dos Institutos Federais de Educação, Ciência e Tecnologia (IFESTS)? In: MOLL, Jaqueline (Org.). Educação profissional e tecnológica no Brasil contemporâneo: desafios, tensões e possibilidades. Porto Alegre: Artmed, 2010.

CONCEFET. Manifestação do Concefet sobre os Institutos Federais de Educação, Ciência e Tecnologia. Revista Brasileira de Educação Profissional e Tecnológica. Brasília: SETEC, v. 1, n. 1. 2008.

CONIF. Nota aberta publicada em 29 de dezembro de 2015. Disponível em:< http://portal.conif.org.br/ultimas-noticias/887-institutos-federais-completam-seteanos.html> Acesso em 06 jan. 2016.

EVANGELISTA, Olinda. Apontamentos para o trabalho com documentos de política educacional. In: ARAÚJO, Ronaldo Marcos de Lima; RODRIGUES, Doriedson S. (Orgs.). A pesquisa em trabalho, educação e políticas educacionais. Campinas (SP): Alínea, 2012.

EVANGELISTA, Olinda. 0 que revelam os slogans na política educacional. Araraquara: Junqueira \& Marin Editores, 2014.

FAIRCLOUGH, Norman. Discurso e mudança social. Brasília: Editora UnB, 2001.

FRIGOTTO, Gaudêncio. Exclusão e/ou inclusão social? questões teóricas e político práticas. Cadernos de Educação (UFPel), v. 1, p. 417-442, 2010.

FRIGOTTO, Gaudêncio. Educação para a "inclusão" e a "empregabilidade": promessas que obscurecem a realidade. In: RUMMERT, Sonia Maria; CANÁRIO, Rui (Orgs.). Mundos do trabalho e aprendizagem. Lisboa: EDUCA, 2009.

FRIGOTTO, Gaudêncio. Os circuitos da história e o balanço da educação no Brasil na primeira década do século XXI. Revista Brasileira de Educação. v. 16, n. 46, jan./abr. 2011.

FRIGOTTO, Gaudêncio. Exclusão e/ou desigualdade social? questões teórico práticas. In: 
Maria Ciavatta. (Org.). Gaudêncio Frigotto: um intelectual crítico nos pequenos e nos grandes embates. 1.ed. Belo Horizonte: Quartet, 2012.

FRIGOTTO, Gaudêncio; CIAVATTA, Maria. Educar o trabalhador cidadão produtivo ou o ser humano emancipado? Revista Trabalho, Educação e Saúde, Rio de Janeiro: Fiocruz, p. 4560., 2003.

GARCIA, Rosalba Maria Cardoso. Políticas públicas de inclusão: uma análise no campo da educação especial brasileira. 2004. Tese (Doutorado em Educação) - Universidade Federal de Santa Catarina - Programa de Pós Graduação em Educação. Florianópolis, 2004.

INSTITUTO FEDERAL DE SANTA CATARINA. Plano de inclusão IFSC 2009-2013.

Florianópolis, 2009. Disponível em:

<https://intranet.ifsc.edu.br/images/file/Publicacoes/Plano\%2olnclusao\%202009-2013.pdf>. Acesso em: 25 fev. 2016.

INSTITUTO FEDERAL DE SANTA CATARINA. Resolução CEPE/IFSC Nº 01/2010.

Regulamenta a Assistência Estudantil do IFSC. Florianópolis, 2010a. Disponível em: <http://www.ifsc.edu.br/ass-legislacao>. Acesso em: 15 dez. 2015.

INSTITUTO FEDERAL DE SANTA CATARINA. Documento referência para Assistência Estudantil do IFSC. Florianópolis, 2010b. Disponível em: http://www.ifsc.edu.br/asslegislacao. Acesso em: 12 nov. 2015.

INSTITUTO FEDERAL DE SANTA CATARINA. Plano de Desenvolvimento Institucional 20152019. Florianópolis, 2014a. Disponível em: <http://pdi.ifsc.edu.br/>. Acesso em 19 fev. 2016.

INSTITTO FEDERAL DE SANTA CATARINA. Resolução Nº 54/2011. Regulamenta o Programa de Atendimento Básico e o Programa de Auxílio Complementar da Assistência Estudantil do IFSC. Florianópolis, 2011.

INSTITUTO FEDERAL DE SANTA CATARINA. Resolução № 47/2014. Regulamenta o Programa de Atendimento ao Estudante em Vulnerabilidade Social do IFSC. Florianópolis, 2014b. Disponível em: <http://www.ifsc.edu.br/ass-legislacao>. Acesso em: 15 nov. 2015.

INSTITUTO FEDERAL DE SANTA CATARINA. Editais PAEVS 2012/Assistência Estudantil No 001/2012, de 17 de fevereiro de 2012. Disponível em: <http://www.ifsc.edu.br/paevs>. Acesso em 02 fev. 2016.

INSTITUTO FEDERAL DE SANTA CATARINA. Edital PAEVS / Assistência Estudantil Nº 002/2012, de 21 de setembro de 2012. Disponível em:

<http://www.ifsc.edu.br/paevs/paevs-editais-anteriores>. Acesso em 02 fev. 2016.

INSTITUTO FEDERAL DE SANTA CATARINA. Edital PAEVS / Assistência Estudantil No 001/2013, de 17 de fevereiro de 2013. Disponível em: <http://www.ifsc.edu.br/paevs/paevseditais-anteriores>. Acesso em 02 fev. 2016. 
INSTITUTO FEDERAL DE SANTA CATARINA. Edital PAEVS / Assistência Estudantil No 002/2013, de 20 de fevereiro de 2013. Disponível em:

<http://www.ifsc.edu.br/paevs/paevs-editais-anteriores>. Acesso em 02 fev. 2016.

INSTITUTO FEDERAL DE SANTA CATARINA. Edital PAEVS / Assistência Estudantil No 004/2013, de 22 de março de 2013. Disponível em: <http://www.ifsc.edu.br/paevs/paevseditais-anteriores>. Acesso em 03 fev. 2016.

INSTITUTO FEDERAL DE SANTA CATARINA. Editais PAEVS / Assistência Estudantil Nº01, 002 e 003/2014, de 17 de fevereiro de 2014. Disponível em:

<http://www.ifsc.edu.br/paevs/paevs-editais-anteriores>. Acesso em 04 fev. 2016.

INSTITUTO FEDERAL DE SANTA CATARINA. Editais PAEVS / Assistência Estudantil No 004 e 005/2014, de 14 de julho de 2014. Disponível em: <http://www.ifsc.edu.br/paevs/paevseditais-anteriores>. Acesso em 05 fev. 2016.

INSTITUTO FEDERAL DE SANTA CATARINA. Edital PAEVS / Assistência Estudantil No 001/2015, de 27 de janeiro de 2015. Disponível em: <http://www.ifsc.edu.br/paevs/paevseditais-anteriores>. Acesso em 06 fev. 2016.

INSTITUTO FEDERAL DE SANTA CATARINA. Edital PAEVS / Assistência Estudantil Nº 002/2015, de 05 de fevereiro de 2015. Disponível em:

<http://www.ifsc.edu.br/paevs/paevs-editais-anteriores>. Acesso em 06 fev. 2016.

INSTITUTO FEDERAL DE SANTA CATARINA. Atas CONSUP 2a Reunião Ordinária -16 de maio de 2012. Disponível em:

$<$ http://cs.ifsc.edu.br/portal/index.php?option=com_content\&view=section\&layout=blog \&id=7\&ltemid=25>. Acesso em: 05 jan. 2016.

INSTITUTO FEDERAL DE SANTA CATARINA. Ata CONSUP $\mathbf{1}^{\mathrm{a}}$ reunião ordinária - $\mathbf{2 7}$ de fevereiro de 2013. Disponível em:

$<$ http://cs.ifsc.edu.br/portal/index.phpoption=com_content\&view=section\&layout=blog\&i $\mathrm{d}=7$ \&ltemid=25>. Acesso em: 05 jan. 2016.

INSTITUTO FEDERAL DE SANTA CATARINA. Ata CONSUP $4^{\mathrm{a}}$ reunião ordinária - 22 de agosto de 2013. Disponível em:

<http://cs.ifsc.edu.br/portal/index.php?option=com_content\&view=section\&layout=blog \&id=7\&ltemid=25>. Acesso em: 05 jan. 2016.

INSTITUTO FEDERAL DE SANTA CATARINA. Ata CONSUP $33^{\text {a }}$ reunião ordinária - 17 de dezembro de 2014. Disponível em:

$<$ http://cs.ifsc.edu.br/portal/index.php?option=com_content\&view=section\&layout=blog \&id=7\&ltemid=25>. Acesso em: 05 jan. 2016.

KOSIK, Karel. Dialética do concreto. 7. ed., Rio de Janeiro: Paz e Terra, 2002. 
KUENZER, Acácia Zeneida. As políticas de educação profissional: uma reflexão necessária. In: MOLL, Jaqueline (Org.). Educação profissional e tecnológica no Brasil contemporâneo: desafios, tensões e possibilidades. Porto Alegre: Artmed, 2010.

LEITE, Janete Luzia. Política de Assistência Estudantil: direito da carência ou carência de direitos? SER Social, Brasília, v. 14, n. 31, p. 453-472, jul./dez., 2012.

MARX, Karl; ENGELS, Friedrich. A ideologia alemã. $2^{\text {a }}$ ed. São Paulo: Martins Fontes, 1998. MÉSZÁROS, István. Para além do capital: rumo a uma teoria da transição. São Paulo: Boitempo, 2002.

MÉSZÁROS, István. A montanha que devemos conquistar: reflexões acerca do Estado. São Paulo: Boitempo, 2015.

MIRANDA, Marília Gouvea de. A organização escolar em ciclos e a questão da igualdade substantiva. Revista Brasileira de Educação. v.14, n.40, 2009. Disponível em: <http://www.scielo.br/scielo.php?script=sci_arttext\&pid=S1413-24782009000100003>. Acesso em 05 jun. 2016.

MOTTA, Vânia Cardoso da. Da ideologia do capital humano à ideologia do capital social: as políticas de desenvolvimento do milênio e os novos mecanismos hegemônicos de educar para o conformismo. 2007. Tese (Doutorado em Serviço Social) - Universidade Federal do Rio de Janeiro - Programa de Pós-graduação em Serviço Social. Rio de Janeiro, 2007.

MOTTA, Vânia Cardoso da. Gerar capital social: tarefa da educação periférica segundo Banco Mundial. In: SEMINÁRIO DO TRABALHO, ECONOMIA E EDUCAÇÃO, VI, Marília, 2008. Anais Anais VI Seminário do trabalho, Economia e Educação. Marília (SP): UNESP 2008. Disponível em:

<http://www.estudosdotrabalho.org/anais6seminariodotrabalho/vaniacardosodamotta.p df>. Acesso em: 24 jan. 2016.

MOTTA, Vânia Cardoso da. Ideologias do capital humano e do capital social: da integração à inserção e ao conformismo. Trab. Educ. Saúde, v. 6, n. 3, p. 549-571, nov.2008/fev.2009.

MOTTA, Vânia Cardoso da. Mudanças no pensamento sobre desenvolvimento: o novodesenvolvimentismo brasileiro. In: JORNADA INTERNACIONAL DE POLÍTICAS PÚBLICAS, V, São Luís (MA), 2011. Anais Anais V Jornada Internacional de Políticas Públicas .

Disponível em:

<http://www.joinpp.ufma.br/jornadas/joinpp2011/CdVjornada/JORNADA_EIXO_2011/DESA FIOS_E_DIMENSOES_CONTEMPORANEAS_DO_DESENVOLVIMENTO_REGIONĀL/MUDAN CAS_NO_PENSAMENTO_SOBRE_DESENVOLVIMENTO.pdf.>. Acesso em: 05 abr. 2016.

NETTO, José Paulo. Uma face contemporânea da barbárie. Revista Novos Rumos. Marília (SP): Unesp, v. 50, n. 01, p. 01-39, 2013.

PINTO, Álvaro Vieira. O conceito de tecnologia. Rio de Janeiro: Contraponto, 2005. (v. 2) 
RECH, Julia Gonçalves. O caráter humanitário da formação dos sujeitos da educação especial no Instituto Federal de Santa Catarina. 2012. Dissertação (Mestrado em Educação) - Universidade Federal de Santa Catarina - Programa de Pós-Graduação em Educação. Florianópolis, 2012.

SHIROMA, Eneida. Oto; CAMPOS, R. F.; GARCIA, R. M. C. Decifrar textos para compreender a política: subsídios teórico-metodológicos para análise de documentos. Perspectiva, Florianópolis, v. 23, n. 2, p. 427-446, 2005.

SILVA, Mariléia Maria da. Percursos profissionais e a justeza das políticas públicas de inclusão e qualificação: o público-alvo do Projovem Trabalhador. In: SILVA, Mariléia Maria da; EVANGELISTA, Olinda; QUARTIERO, Elisa Maria (Orgs). Jovens, trabalho e educação: a conexão subalterna de formação para o capital. Campinas, SP: Mercado das Letras, 2012.

STOLF, Franciele. Assistência estudantil na Universidade Federal de Santa Catarina: uma análise inicial do Programa Bolsa Estudantil. 2014. Dissertação (Mestrado em Educação) Universidade Federal de Santa Catarina - Programa de Pós-Graduação em Educação.

Florianópolis, 2014.

VAZ, Joana D'Arc. Educação, programa bolsa família e alívio à pobreza: o cinismo instituído. 2013. Dissertação (Mestrado em Educação) - Universidade Federal de Santa Catarina - Programa de Pós-Graduação em Educação. Florianópolis. 2013.

Recebido em: 03/05/2016 Aprovado em: 11/06/2016

Universidade do Estado de Santa Catarina - UDESC Programa de Pós-Graduação em Educação - PPGE Revista Linhas Volume 17 - Número 35 - Ano 2016 revistalinhas@gmail.com 